\title{
An Evaluation of 17 Grasses and 2 Legumes for Revegetation of Soil and Spoil on a Coal Strip Mine
}

\author{
PAULA J. NICHOLAS AND WILLIAM J. MCGINNIES
}

\begin{abstract}
Seventeen grass species and two legumes were evaluated in a greenhouse study to determine their potential for revegetation of coal strip mine areas. Each species was grown in $25 \mathrm{~cm}$ of topsoil placed over $28 \mathrm{~cm}$ of mine-spoil or in $53 \mathrm{~cm}$ of spoil without topsoil. Herbage yields were seven times greater and root yields six times greater when the grasses were grown in topsoil than when grown in spoil without topsoil. When herbage production, root production, and crude protein were considered together and given equal weight, the five species with the highest combined ratings when grown in $25 \mathrm{~cm}$ of topsoil over spoil were tall fescue, hard fescue, Russian wildrye, western wheatgrass, and Arizona fescue. All grass species studied produced relatively low yields when grown in spoil without topsoil. Average herbage yields for the native and introduced grass species studied were similar, but introduced species averaged greater root production, particularly in spoil material. Two legumes, alfalfa and cicer milkvetch, produced much higher yields and higher crude protein than any of the grasses studied whether grown in topsoil over spoil or in spoil without topsoil.
\end{abstract}

In reclamation of disturbed lands, establishment of a beneficial plant cover is essential for site stabilization and for the proposed future use of the area. Use of species adapted to the soil, climate, elevation, and exposure of the site has been suggested for successful establishment of vegetation (Cook et al. 1974, Currier 1971, Plummer et al. 1968) on coal strip mine lands. However, relatively little has been reported on the actual growth patterns of these adapted plant species on reclaimed strip mine sites.

Herbage growth patterns of plant species used for reclamation purposes are important to consider for site stabilization, game habitat, forage production, and aesthetic values. Studies in northwest Colorado (Berg and Barrau 1973, McGinnies and Nicholas 1980), North Dakota (Ries et al. 1977; Power et al. 1976, 1978, 1979), Wyoming (Dollhopf et al. 1977, Schuman and Taylor 1978), and Montana (Dusek 1975, Farmer et al. 1974, Hodder 1973, Richardson et al. 1975) have evaluated the above-ground growth of several plant species, particularly grasses, grown on various depths of topsoil over spoil, topsoil and spoil mixtures, and in spoil alone. Several grass and legume species appear to produce adequate above-ground growth for reclamation purposes.

Collecting root yield data is difficult, so very little is actually known about root growth patterns in undisturbed soils let alone in disturbed soils such as those created by the strip mining process. Hafenrichter et al. $(1949,1968)$ described normal root patterns for several grass and legume species used for soil conservation in the Pacific Northwest and the northern Great Basin. Weaver (1926,

\footnotetext{
Authors are range technician and range scientist, respectively, U.S. Dep. Agr., Agr. Res. Serv., Crops Research Laboratory, Colorado State University, Fort Collins 80523.

Cooperative investigations of U.S. Dep. Agr., Agr. Res. Serv., Fort Collins, Colorado and the Colorado Agricultural Experiment Station, Fort Collins, Published with approval of the Director of the Colorado Agricultural Experiment Station as Scientific Series No. 2581. This research was funded in part by the Environmental Protection Agency.

Manuscript received September 11, 1980.
}

1950), Weaver and Darland (1949), and others (Gist and Smith 1948 , Sprague 1933) have studied root systems in natural grassland communities and in croplands in several parts of the country.

Root growth into spoil materials should contribute to the stabilization of disturbed sites, enhance soil development processes, and increase chances of plant survival during periods of drought. Roots below $50 \mathrm{~cm}$ normally comprise only a small fraction of the total root biomass but are extremely important in providing water and nutrients to plants late in the growing season. Schafer et al. (1977) found that 3 to 4 years were required before root systems of plants grown in mine spoils resembled those in natural soils in weight and distribution. In many of the youngest mine spoils, over $90 \%$ of the roots were found above $25 \mathrm{~cm}$, which suggests that shallow roots develop first in reclaimed plant communities; even in old mine spoils, $63 \%$ of the roots occurred above $25 \mathrm{~cm}$.

In a previous study (McGinnies and Nicholas 1980), we found that above- and below-ground growth of intermediate wheatgrass and wheat increased with topsoil thickness (up to the $46 \mathrm{~cm}$ of topsoil thickness studied). When topsoil was placed over spoil under greenhouse conditions, intermediate wheatgrass produced more roots in the top $25 \mathrm{~cm}$ of topsoil and many more roots in the spoil below than did wheat, so it should provide better soil stability. In the field during the second growing season, stand ratings of a mixture of grasses increased with increased topsoil thickness (up to $46 \mathrm{~cm}$ of topsoil). These results prompted further interest in evaluating the growth characteristics of species currently used in revegetation programs when grown in topsoil over spoil and in spoil without topsoil.

The greenhouse study was designed to (1) evaluate herbage and root growth of 17 grass and 2 legume species when grown in $25 \mathrm{~cm}$ of topsoil placed over spoil and in spoil without topsoil and to (2) determine the protein content of the herbage and roots of the grass and legume species studied.

\section{Methods}

Topsoil and spoil material used in the study wcre obtained from Energy Fuels Mine No. 1. located $32 \mathrm{~km}$ ( 20 miles) southwest of Steamboat Springs, Colorado. Elevation was 2,135 m (7,000 ft) and average annual precipitation was $41 \mathrm{~cm}$ ( $16 \mathrm{in}$.). The soil was a Routt Loam and was classified as a fine, montmorillonitic Typic Argiboroll. Topsoil (primarily A horizon material) was obtained from an undisturbed sagebrush area. The spoil material was obtained from the Williams Fork Formation of the upper Cretaceous Mesa Verde Groups and was of a mixture of shale and sandstone. Topsoil and spoil characteristics are summarized in Table 1.

Cans were made of galvanized metal (stove) pipes, $15 \mathrm{~cm}(6$ inches) in diameter by $61 \mathrm{~cm}$ (24 in.) in length, and were plugged on the bottom with a wood plug which allowed for drainage. The cans were filled with $28 \mathrm{~cm}$ (11 in.) or $53 \mathrm{~cm}$ (21 in.) of spoil material. Spoil material was passed through a $1.3-\mathrm{cm}$ mesh screen to eliminate very large rock materials common to spoil. Twenty-five $\mathrm{cm}$ (10 in.) and $0 \mathrm{~cm}$ of topsoil were placed on top of 28 or $53 \mathrm{~cm}$ of 
Table 1. Chemical and physical analyses of soil and spoil material used in the greenhouse study.

\begin{tabular}{|c|c|c|c|c|c|c|c|c|c|c|c|}
\hline & \multirow{2}{*}{$\mathrm{pH}^{1}$} & \multirow{2}{*}{ SAR } & \multirow{2}{*}{$\begin{array}{c}\text { EC } \\
(\mathrm{mmhos} / \\
\mathrm{cm})\end{array}$} & $\begin{array}{c}\text { Kjeldahl } \\
\mathbf{N} \\
\end{array}$ & $\begin{array}{l}{\mathrm{Na} \mathrm{HCO}_{3}-}_{\text {extractable }} \\
\text { P } \\
\end{array}$ & $\mathrm{Ca}^{2}$ & $\mathrm{Mg}$ & $\mathrm{Na}$ & \multirow[t]{2}{*}{ Sand } & \multirow{2}{*}{$\frac{\text { Silt }}{(\%)}$} & \multirow[t]{2}{*}{ Clay } \\
\hline & & & & \multicolumn{2}{|c|}{$(\mathrm{ppm})$} & \multicolumn{3}{|c|}{$(\mathrm{meq} / 1)$} & & & \\
\hline Topsoil & 5.9 & 0.04 & 0.32 & 2824 & 40 & 5.2 & 3.0 & 0.1 & 53 & 19 & 28 \\
\hline Spoil & 7.0 & 0.24 & 0.88 & 1825 & 4 & 23.2 & 26.2 & 1.2 & 42 & 30 & 28 \\
\hline
\end{tabular}

'Saturation paste.

${ }^{2} \mathrm{Ca}, \mathrm{Mg}$, and $\mathrm{Na}$ from saturation paste extract.

spoil material, respectively.

The green house temperature averaged $22^{\circ} \mathrm{C}$. Sunlight was augmented with sodium-vapor lights and light intensity ranged from a maximum PAR of $1000 \mu \mathrm{E} \mathrm{m}^{-2} \mathrm{sec}^{-1}$ to a minimum of $100 \mu \mathrm{E} \mathrm{m}^{-2}$ $\sec ^{-1}$. Day length was 14 hours.

Each can was planted on December 12, 1977, with 10 seeds of one of the 17 grass or 2 legume species. All species were planted 1-2 $\mathrm{cm}$ deep, except for timothy, orchardgrass, and hard fescue, which were planted $0.5 \mathrm{~cm}$ deep. Legume seeds were treated with inoculant. Four replications were made of each plant species on each of the two topsoil thickness treatments. Plants were thinned on January 25,1978 , to leave the three most vigorous seedlings.

Herbage was harvested on February 21, 1978, and again on March 30, 1978. Cans were split lengthwise in late May, 1978, and the soil and spoil were washed from the roots. The roots were separated from the herbagc, and then the roots were separated into those growing in the topsoil and those growing in the spoil. All separated herbage and root material was oven-dried at $60^{\circ} \mathrm{C}$ and weighed. Total herbage production was the sum of the herbage harvests made in February, March, and May.

Nitrogen content of all herbage and root materials was determined using a modified Kjeldahl procedure (Isaac and Johnson 1976). The data were converted to crude protein by multiplying $\%$ nitrogen by 6.25 .

Data were analyzed by standa rd analysis of variance techniques. Tukey's "Honestly Significant Difference" test was used where needed to evaluate differences between means. The term "significant" is used in this paper to refer to statistical significance at a probability equaling or exceeding 0.05 .

\section{Results and Discussion}

All species produced more herbage and more roots in the topsoil treatment than in the spoil alone treatment. Root production was greater in the topsoil than in the underlying spoil or in the upper 25 $\mathrm{cm}$ of the spoil alone treatment (Fig. 1). The higher yields from the

BIOMASS YIELD $(g / c O n)$

$25 \mathrm{CM}$ TOPSOIL OVER SPOIL

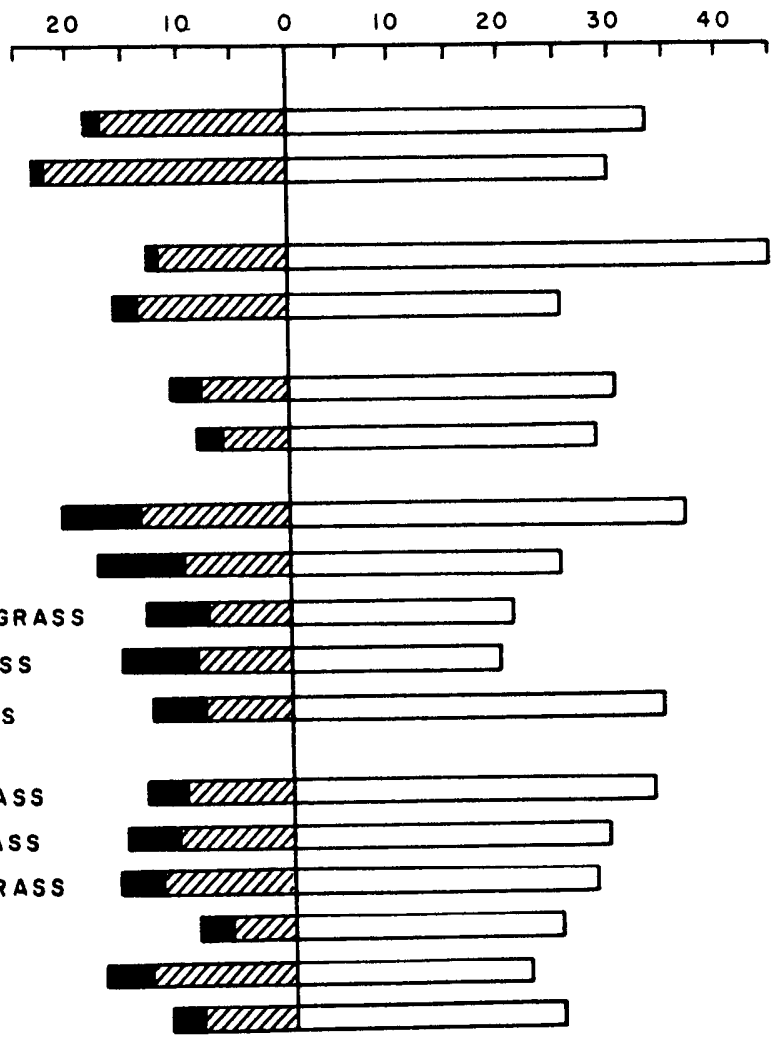

SPOIL ALONE

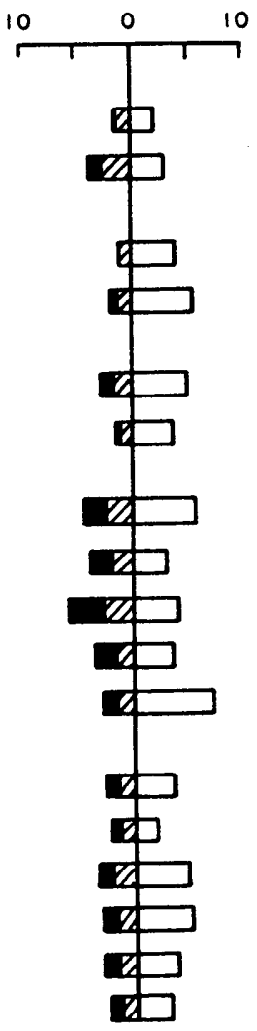

HERBAGE YIELD

ROOT YIELD

ABOVE $25 \mathrm{cM}$

BELOW $25 \mathrm{CM}$
Fig. 1. Herbage and root production of the 17 grasses grown in $25 \mathrm{~cm}$ of topsoil over spoil and in spoil alone in the greenhouse. Group I, fine-leaf fescues; Group II, pasture grasses; Group III, short-lived native grasses;
Group IV, grasses with 35 to $45 \%$ of root growth in spoil under topsoil; Group V, other grasses. 
topsoil treatment confirm and augment previously reported results (McGinnies and Nicholas 1980). Soil moisture was adequate in both topsoil and spoil materials and there were no known physical or chemical impediments to plant growth in the spoil material. Therefore, the increased yield in the topsoil treatment is believed to result from higher available nitrogen and phosphorus levels in the topsoil material (McGinnies and Nicholas 1980).

For purposes of discussion, the grass species studied have been grouped on the basis of the root growth characteristics, life history, whether native or introduced, and productivity (Fig. 1). The survival and productivity of vegetation on reclaimed lands probably depends on the ability of plant species to extend a substantial portion of their root system through a relatively shallow topsoil layer and into the underlying spoil material. Roots growing into spoil materials can be expected to contribute to the stability of disturbed sites, enhance soil development processes, and increase chances of plant survival.

\section{Group I}

The first group includes the two fine-leaved fescues studied, Arizona fescue (Festuca arizonica) and hard fescue (Festuca ovina duriuscula). Both grasses formed a dense mat of fine roots near the soil surface, and relatively few roots penetrated int o the spoil below the $25 \mathrm{~cm}$ of topsoil. Hard fescue, an introduced bunchgrass, normally develops high root yields in the upper $20 \mathrm{~cm}$ ( 8 inches) of the soil profile (Hafenrichter et al. 1968). When grown in $25 \mathrm{~cm}$ of topsoil over spoil, hard fescue produced high root yields in the upper $25 \mathrm{~cm}$, high total root yields, and high total biomass yields relative to the other grass species studied; however, root yields below $25 \mathrm{~cm}$ were low (Fig. 2, upper left). Root yields of hard fescue were high when it was grown in spoil without topsoil, but again, these roots were located near the soil surface.

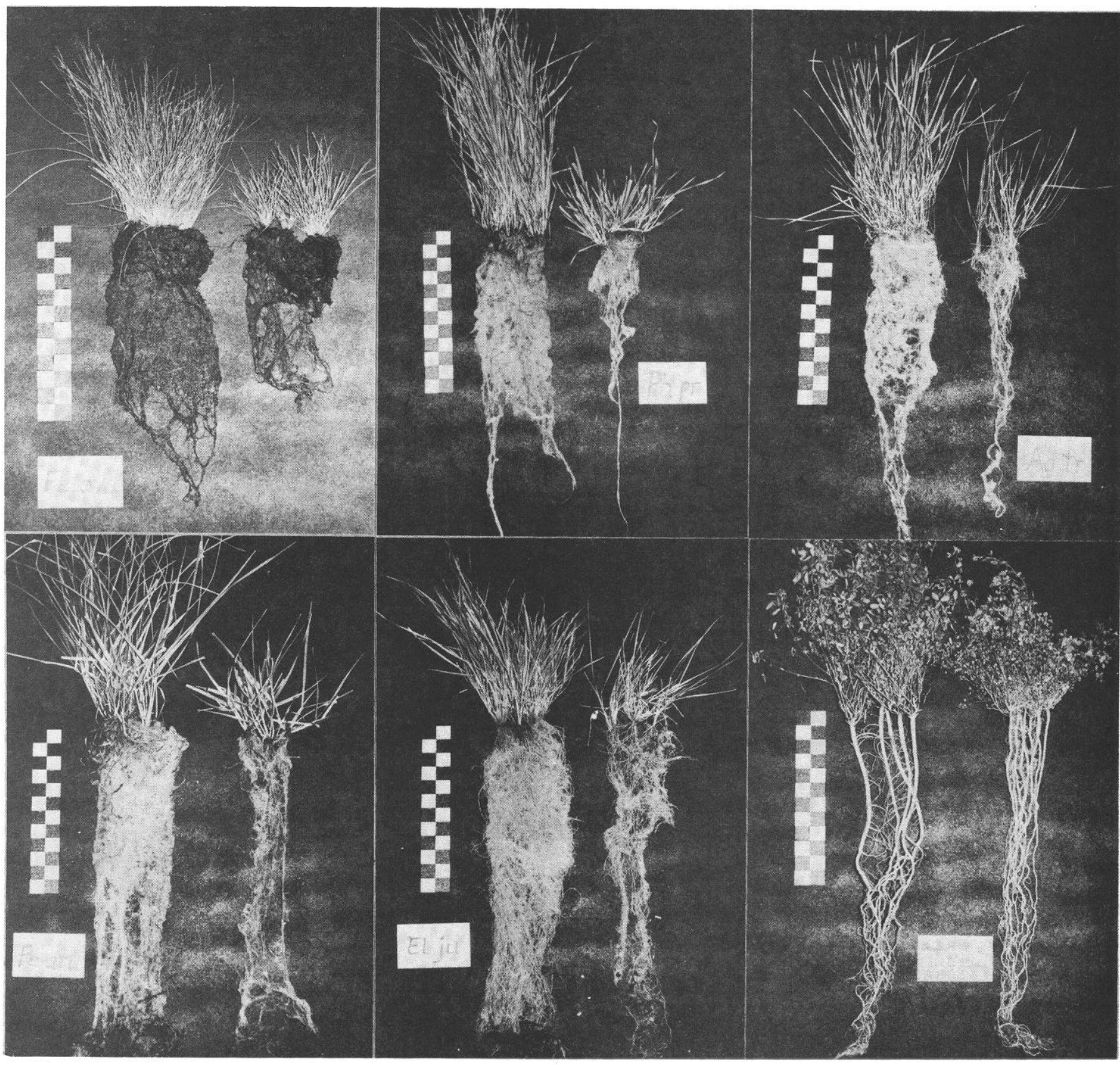

Fig. 2. Plants grown on $25 \mathrm{~cm}$ topsoil over spoil (left-hand plant of each pair) and on spoil alone (right-hand plant), after 5 months in the greenhouse. Upper left, hard fescue; upper center, timothy; upper right, slender wheatgrass; lower left, tall fescue; lower center, Russian wildrye; lower right, alfalfa. 
Arizona fescue, a native bunchgrass, also produced high root yields in the upper $25 \mathrm{~cm}$ and high total biomass yields when grown in topsoil over spoil. When grown in spoil alone, it produced low root yields above and below $25 \mathrm{~cm}$, and therefore, a very low total biomass. This may be an example of a climax species being unable to make satisfactory growth in a pioneer situation.

\section{Group II}

The second group includes two normally high yielding, although generally short-to-medium lived, introduced pasture bunchgrass species, timothy (Phleum pratense) and orchardgrass (Dactylis glomerata). Timothy produced high root yields when grown in topsoil, but also the lowest root yields of all grasses studied when grown in spoil without topsoil (Fig. 2, upper center).

Compared to that by timothy, herbage production by orchardgrass was lower, although root growth in spoil without topsoil was greater. Orchard grass normally produces a dense mass of mediumsized roots and has been useful elsewhere for soil conservation purposes (Hafenrichter et al. 1968).

\section{Group III}

Two rapidly developing, short-lived, native bunchgrasses, mountain brome (Bromus marginatus) and slender wheatgrass (Agropyron trachycaulum), comprise the third group. Both grasses have been fairly easy to establish in field plantings. In the greenhouse, herbage production of mountain brome and slender wheatgrass was average relative to other species studied whether grown in topsoil or in spoil without topsoil. When grown in topsoil, these two species both produced low root yields; however, both produced more roots that penetrated into the spoil below the $25 \mathrm{~cm}$ of topsoil than did any species in Groups I or II. Mountain brome produced average root yields and slender wheatgrass produced poor root yields when grown in spoil alone. Both species are fairly common invaders in disturbed areas, so it was a surprise to find that they did not produce better root systems when grown in spoil (Fig. 2, upper right).

\section{Group IV}

The fourth group includes tall fescue (Festuca arundinacea), Russian wildrye (Elymus junceus), pubescent wheatgrass (Agropyron intermedium var. trichophorum), intermediate wheatgrass ( $A$. intermedium), and western wheatgrass ( $A$. smithii). These five species demonstrated moderate to high root production in the topsoil but had 35 to $45 \%$ of the total root mass occurring in the spoil underlying the $25 \mathrm{~cm}$ of topsoil. They also generally produced high root yields when grown in spoil without topsoil. Tall fescue, an introduced and naturalized bunchgrass, is normally considered a good ground cover because of the large amount of coarse, tough roots produced in the upper $20 \mathrm{~cm}$ ( 8 inches) of the soil profile and because it usually produces good yields on poorly drained soils and on wet saline or saline-alkali soils (Hafenrichter et al. 1968). However, it will usually not endure long periods of drought. Tall fescue produced and second greatest herbage and total root growth of all grasses studied whether grown in topsoil over spoil or in spoil without topsoil (Fig. 2, lower left).

Root production of Russian wildrye, an introduced bunchgrass, was almost as great as that of tall fescue, but Russian wildrye produced considerably less herbage growth (Fig. 2, lower center). Russian wildrye has shown the greatest persistence of those species tested at intermediate elevations in western Colorado (McGinnies unpublished data).

Intermediate wheatgrass, an introduced sodgrass, produced the highest root yields in the greenhouse of all grass species tested when grown in spoil without topsoil; however, its herbage production was only average. Pubescent wheatgrass is taxonomically similar to intermediate wheatgrass. It is usually considered to be a vigorous introduced sod-forming grass that is very productive and persistent on harsh sites. While herbage production of pubescent wheatgrass was amongst the lowest of the grasses studied, its root production was above average whether grown in topsoil or in spoil. Both intermediate and pubescent wheatgrass have been planted extensively in northwest Colorado.

Western wheatgrass, normally a vigorous native sodgrass, produced slightly below average root yields, but herbage yields were third highest of all grasses tested when grown on topsoil. When grown in spoil without topsoil, it produced average root yields but, again, above average herbage yields.

\section{Group V}

The fifth group was comprised of six grass species that did not fit into any one of the preceding groups. Thickspike (Agropyron dasystachyum), beardless ( $A$. spicatum var. inerme), streambank ( $A$. riparium), and desert wheatgrasses ( $A$. desertorum), smooth brome (Bromus inermis), and basin wildrye (Elymus cinereus) were mostly average or below average in both herbage and root production compared to the other grasses studied. Their root

Table 2. Average protein content (\%) of herbage and root materials of 17 grasses grown in $25 \mathrm{~cm}$ of topsoil over spoil and in spoil alone.

\begin{tabular}{|c|c|c|c|c|c|c|}
\hline \multirow[b]{3}{*}{ Species } & \multicolumn{3}{|c|}{ Spoil alone } & \multicolumn{3}{|c|}{ Topsoil } \\
\hline & \multirow[b]{2}{*}{ Herbage $^{1}$} & \multicolumn{2}{|c|}{ Roots } & \multirow[b]{2}{*}{ Herbage $^{1}$} & \multicolumn{2}{|c|}{ Roots } \\
\hline & & Upper $25 \mathrm{~cm}$ & Below $25 \mathrm{~cm}$ & & Upper $25 \mathrm{~cm}$ & Below $25 \mathrm{~cm}$ \\
\hline Thickspike wheatgrass & 5.94 & 4.75 & 4.25 & 7.06 & 5.69 & 4.75 \\
\hline Desert wheatgrass & 9.06 & 5.38 & 4.81 & 10.94 & 6.81 & 5.19 \\
\hline Beardless wheatgrass & 10.94 & 5.06 & 5.56 & 6.50 & 6.25 & 4.69 \\
\hline Intermediate wheatgrass & 8.81 & 4.88 & 4.69 & 8.63 & 5.06 & 3.94 \\
\hline Western wheatgrass & 6.94 & 5.81 & 5.06 & 9.94 & 6.31 & 5.38 \\
\hline Streambank wheatgrass & 6.06 & 4.38 & 4.38 & 8.00 & 6.25 & 5.06 \\
\hline Pubescent wheatgrass & 8.06 & 5.00 & 4.25 & 8.06 & 5.31 & 3.75 \\
\hline Slender wheatgrass & 7.63 & 4.69 & 5.00 & 11.06 & 7.50 & 5.94 \\
\hline Smooth brome & 7.44 & 5.06 & 4.00 & 5.81 & 5.06 & 4.56 \\
\hline Mountain brome & 7.06 & 4.44 & 4.19 & 7.31 & 5.25 & 4.00 \\
\hline Orchardgrass & 5.88 & 4.63 & 4.38 & 7.38 & 5.44 & 5.31 \\
\hline Basin wildrye & 9.56 & 7.69 & 5.81 & 8.19 & 7.13 & 6.56 \\
\hline Russian wildrye & 10.75 & 4.94 & 5.31 & 10.75 & 7.19 & 5.50 \\
\hline Arizona fescue & 7.19 & 4.69 & -2 & 6.75 & 4.56 & - \\
\hline Tall fescue & 7.81 & 5.63 & 4.50 & 9.25 & 5.00 & 5.00 \\
\hline Hard fescue & 9.13 & 5.81 & - & 9.56 & 5.06 & - \\
\hline Timothy & 3.94 & 5.13 & - & 8.38 & 5.50 & - \\
\hline Tukey's HSD (0.05) & 3.75 & N.S. & 1.06 & N.S. & 1.94 & 1.25 \\
\hline
\end{tabular}

INitrogen was determined for herbage from the third clipping only.

2 Not enough root material for a nitrogen analysis. 
Table 3. Average protein content (\%) of herbage and root materials of two legumes grown in $25 \mathrm{~cm}$ of topsoil over spoil and in spoil alone.

\begin{tabular}{|c|c|c|c|c|c|c|}
\hline \multirow[b]{3}{*}{ Species } & \multicolumn{3}{|c|}{ Spoil alone } & \multicolumn{3}{|c|}{ Topsoil } \\
\hline & \multirow[b]{2}{*}{ Herbage } & \multicolumn{2}{|c|}{ Roots } & \multirow[b]{2}{*}{ Herbage ${ }^{1}$} & \multicolumn{2}{|c|}{ Roots } \\
\hline & & Upper $25 \mathrm{~cm}$ & Below $25 \mathrm{~cm}$ & & Upper $25 \mathrm{~cm}$ & Below $25 \mathrm{~cm}$ \\
\hline Cicer milkvetch & $21.06^{2}$ & 10.38 & 10.75 & 17.31 & 8.75 & 10.00 \\
\hline Alfalfa & 18.25 & 7.00 & 13.63 & 19.88 & 5.63 & 7.81 \\
\hline Average & 19.66 & 8.69 & 12.19 & 18.60 & 7.19 & 8.91 \\
\hline
\end{tabular}

'Nitrogen was determined for herbage from the third clipping only.

2Differences between species for \% protein not significantly different for herbage or roots.

growth into the spoil below the $25 \mathrm{~cm}$ of topsoil was only average. Thickspike wheatgrass, a native rhizomatous grass, produced good root growth below $25 \mathrm{~cm}$, and yet, in general, it produced a low total root yield.

Beardless wheatgrass, a native bunchgrass, demonstrated a definite preference for topsoil. This may be another example of a climax species requiring a good soil for successful growth.

Streambank wheatgrass, a native sodgrass that usually produces a good cover because of its strong rhizomes, had slightly better than average herbage and root growth when grown in spoil alone.

Desert, or crested wheatgrass was very disappointing in regard to both herbage and root production when grown in topsoil placed over spoil, but was slightly above average in both regards when grown in spoil without topsoil. Desert wheatgrass has been successfully established and maintained on extensive acreages in northwest Colorado.

Smooth brome is a widely adapted, introduced sodgrass often noted for its high yields of forage, roots, and seed. In the greenhouse, smooth brome produced disappointing herbage yields when grown in topsoil over spoil; however, root yields were above the average of the other species tested. When grown in spoil without topsoil, it produced near average root and herbage yields.

Basin wildrye is a robust, native bunchgrass adapted to a variety of sites and commonly found on poor soils and disturbed sites such as road cuts and fills. In the greenhouse, basin wildrye produced below average herbage and root yields relative to the other species studied when grown in topsoil over spoil. When grown in spoil without topsoil, its root production was much below average. This was unexpected since established stands of basin wildrye have been known to survive extended periods of summer drought on harsh sites.

\section{Group VI}

The two legumes studied, alfalfa and cicer milkvetch, comprise the sixth group (Fig. 3). Herbage production by both legumes was an a verage of $225 \%$ greater than the herbage production of all grass species tested when grown in spoil without topsoil, and $42 \%$ greater when grown in $25 \mathrm{~cm}$ of topsoil placed over spoil. Root production

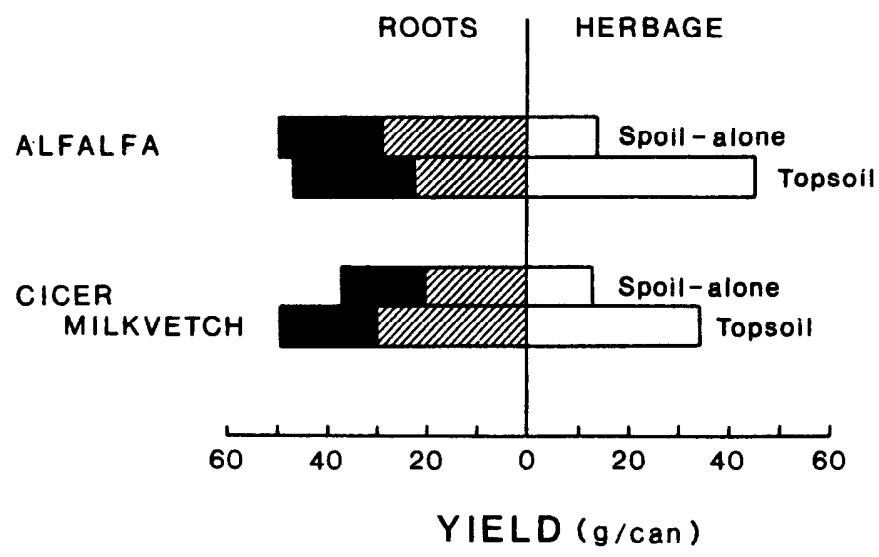

Fig. 3. Herbage and root production of the two legumes studied in the greenhouse grow'n in $25 \mathrm{~cm}$ of topsoil over spoil and in spoil alone. by the legumes was almost three times the average root production of the grasses when grown in topsoil over spoil; when grown in spoil alone, root production by the legumes was 16 times greater than the average root production of the grasses. The increased yields of both herbage and roots is probably due to the ability of the legumes to fix nitrogen, which, in turn, can stimulate growth. Nodulation was observed on legume roots in all replications in both topsoil and spoil.

Alfalfa had slightly higher herbage and root yields than cicer milkvetch. Alfalfa produced an abundance of roots in the spoil under the $25 \mathrm{~cm}$ topsoil treatment and in the spoil-alone treatment (Fig. 2, lower right).

Cicer milkvetch produced slightly less herbage and root growth than alfalfa and had a slightly lower proportion of roots in the spoil under the topsoil than alfalfa. However, the differences between these two legume species are probably not great enough to be of any concern.

\section{Native vs. Introduced Grasses}

Nine of the 17 grass species studied in the greenhouse were introduced species and eight were natives. Average herbage production of native and introduced species was similar and the herbage yields comprised nearly equal proportions of the biomass yields when grown in spoil without topsoil ( $62 \%$ vs. $60 \%$ for native and introduced species, respectively). When grown in topsoil, average herbage yields of native species were higher than the average herbage yields of the introduced species and made up a greater proportion of the biomass ( $70 \%$ vs. $60 \%$ ). However, average total root yields of introduced grasses made up a significantly greater proportion of the biomass than root yields of native grasses whether grown in topsoil over spoil $(40 \%$ vs. $30 \%)$ or in spoil without topsoil ( $46 \%$ vs. $38 \%$ ). The proportion of total root yield in the upper $25 \mathrm{~cm}$ of the soil profile compared to the proportion below $25 \mathrm{~cm}$ for introduced and native species was similar whether grown in topsoil or in spoil without topsoil.

\section{Protein Content}

There was no significant difference in the average percent crude protein of grass herbage (Table 2) when species were grown in 25 $\mathrm{cm}$ of topsoil over spoil $(8.45 \%)$ and in spoil alone $(7.78 \%)$. However, roots of grasses grown in topsoil contained significantly more protein $(5.41 \%)$ than roots grown in spoil alone $(4.95 \%)$.

Average crude protein content of legume herbage was similar for the two species (Table 3) whether grown in topsoil or in spoil alone ( $18.60 \%$ and $19.66 \%$, respectively). In contrast to the grasses, legume roots grown in spoil generally contained more protein than roots grown in topsoil $(10.47 \%$ and $8.05 \%$, respectively).

Protein content of roots is particularly important for soil development processes. When the roots die and decay, their nitrogen is incorporated into soil nitrogen pool and the higher the protein content of the roots, the more nitrogen that will be released into the nitrogen pool. This can be extremely important when spoil materials are deficient in nitrogen.

\section{Conclusions}

Successful reclamation of coal strip mine lands can be achieved when the plant species chosen possess suitable growth characteris- 
tics that will enhance soil stabilization and soil development on the disturbed site. These desirable growth characteristics include high herbage production, a relatively dense root system that dominates the topsoil, and good root penetration into the spoil underneath the topsoil. All of these growth characteristics are rarely possessed by a single species. Furthermore, monocultures may not be desirable for long-term revegetation purposes or even be permitted by regulatory agencies. By selecting a mixture of species with various suitable growth characteristics, revegetation of disturbed lands can be most successful.

Several of the grass species and both legumes studied in the greenhouse produced adequate above- and below-ground growth for revegetation purposes when grown in $25 \mathrm{~cm}$ of topsoil over spoil. If herbage production, root production, and crude protein (a major factor in forage quality) are considered together and given equal weight, the five grass species with the highest combined scores were tall fescue, hard fescue, Russian wildrye, western wheatgrass, and Arizona fescue. However, hard and Arizona fescues did not make good root growth into the spoil material, and thus should probably be considered only as components of a mixture of grass species. Both legumes, alfalfa and cicer milkvetch, produced much higher yields and had higher percentages of crude protein in both herbage and roots than any of the grasses studied.

When grown in spoil without topsoil, all of the grass species studied produced low yields compared to their yields when grown in topsoil over spoil. Again, both legumes produced much higher herbage yields, root yields, and crude protein contents than any of the grasses studied. These two legumes could be beneficial in most reclamation programs whether grown in topsoil over spoil or in spoil alone because of their ability to fix $\mathrm{N}$ and to develop large and deep root systems.

The results reported in this paper are entirely from greenhouse studies. Extensive field observations are now needed to corroborate the findings reported here.

\section{Literature Cited}

Berg, W.A., and E.M. Barrau. 1973. Composition and production of seedings on strip-mine spoils in northwestern Colorado. p. 215-224. In: Proc., First Research and Applied Tech. Symp. on Mined Land Reclamation. Bituminous Coal Research, Inc., Monroeville, Pa. 335 p.

Cook, C.W., R.M. Hyde, and P.L. Sims. 1974. Guidelines for revegetation and stabilization of surface mined areas in the western states. Colorado State Univ., Range Sci. Ser. No. 16. 70 p.

Currier, W.F. 1971. Basic principles of seed planting. p. 100-106. In: Proc., Critical Area Stabilization Workshop, Albuquerque, N. Mex.

Dollhopf, D.J., I.B. Jensen, and R.L. Hodder. 1977. Effects of surface configuration in water pollution control on semi-arid mined lands. Montana Agr. Exp. Sta. Res. Rep. 114, Montana State Univ., Bozeman. 179 p.

Dusek, G.L. 1975. Vegetational responses by substrate, gradient and aspect on a 12 acre test plot in the Bull Mountains. p. 233-246. In: Proc., Fort Union Coal Field Symposium. Eastern Montana College, Billings.
Farmer, E.E., R.W. Brown, B.Z. Richardson, and P.E. Packer. 1974. Revegetation research on the Decker Coal Mine in southwestern Montana. U.S. Dep. Agr. Forest Serv. Res. Paper INT-162. 12 p.

Gist, G.R., and R.M. Smith. 1948. R oot development of several common forage grasses to a depth of eighteen inches. Amer. Soc. Agron. J. 40:1036-1042.

Hafenrichter, A.L., L.A. Mullen, and R.L. Brown. 1949. Grasses and legumes for soil conservation in the Pacific Northwest. U.S. Dep. Agr. Misc. Pub. No. 678. 56 p.

Hafenrichter, A.L., J.L. Schwendiman, H.L. Harris, R.S. MacLauchlan, and H.W. Miller. 1968. Grasses and legumes for soil conservation in the Pacific Northwest and Great Basin States. U.S. Dep. Agr. Soil Conserv. Serv. Agr. Handbook 339, Washington D.C.

Hodder, R.L. 1973. Surface mined land reclamation research in eastern Montana. p. 82-91. In: First Research and Applied Technology Symp. on Mined Land Reclamation. Nat. Coal Ass., Bituminous Coal Research, Inc., Monroeville, Penn.

Isaac, R.A., and W.C. Johnson. 1976. Determination of total nitrogen in plant tissue, using a block digestor. J. of AOAC 59:98-100.

McGinnies, W.J., and P.J. Nicholas. 1980. Effects of topsoil depth and nitrogen fertilizer on the revegetation of coal mine spoils. J. Environ. Quality. 9:681-685.

Plummer, A.P., D.R. Christensen, and S.B. Monsen. 1968. Restoring big game range in Utah. Utah State Dep. Natural Resources, Div. Fish and Game Pub. No. 68-3. 183 p.

Power, J.F., R.E. Ries., and F.M. Sandoval. 1976. Use of soil materials-effect of thickness and quality. No. Dakota Agr. Exp. Sta. reprint No. 891 from Sept.-Oct., 1976 Farm Res. 34(1):23-24.

Power, J.F., R.E. Ries, and F.M. Sandoval. 1978. Reclamation of coalmined land in the northern Great Plains. J. Soil. Water Conserv. 33:6974.

Power, J.F., F.M. Sandoval, and R.E. Ries. 1979. Topsoil-subsoil requirements to restore North Dakota mined lane to original productivity. Soc Mining Enginecring 13:1708-1712. (December).

Richardson, B.Z., E.E. Farmer, R.W. Brown, and P.E. Packer. 1975. Rehabilitation research and its application on a surface mined area of eastern Montana. In: Fort Union Coal Field Symposium Proceedings, Vol. 3, Montana Acad. Sci., Eastern Montana College, Billings.

Ries, R.E., F.M. Sandoval, and J.F. Power. 1977. Reclamation of disturbed lands in the lignite area of the Northern Plains. p. 309-327. In: Proc., 1977 Symp. of Tech. and Use of Lignite (ERDA-UND), Grand Forks, N.D.

Schafer, W.M., G.A. Nielsen, D.J. Dollhopf, and R.L. Hodder. 1977. Soil genesis, hydrological properties, and root characteristics of 2-53 year old stripmine spoils. Montana Agr. Exp. Sta. Res. Rep. 108. Montana State Univ., Bozeman.

Schuman, G.E., and E.M. Taylor, Jr. 1978. Use of mine spoil material to improve the topsoil. Wyoming Agr. Exp. Sta. Res. J. 130, Laramie.

Sprague, H.B. 1933. Root development of perennial grasses and its relation to soil conditions. Soil Sci. 36:189-209.

Weaver, J.E. 1926. Root development of field crops. McGraw Hill, New York.

Weaver, J.E. 1950. Summary and interpretation of underground development in natural grassland communities. Ecol. Monog. 28:55-78.

Weaver, J.R., and R.W. Darland. 1949. Quantitative study of root sytems in different soil types. Sci. 110:164-165. 